\title{
Employment suburbanisation, reverse commuting and travel \\ behaviour by residents of the central city in the Paris metropolitan
}

area

\begin{abstract}
This paper analyses the relationship between employment suburbanisation in the Paris metropolitan area, the growth of reverse commuting and changes in the weekday travel behaviour of working residents of the central city over a 20 years period. The results show that the number of reverse commuters has significantly increased because the municipality of Paris has lost many jobs but few working residents whilst employment has developed in the suburbs. Reverse commuters are mainly and increasingly high income professionals whose workplace is located close to the central city in employment sub-centres that are well served by public transport. Consequently reverse commuters have lower than average car use although differences exist and are related to their professional status. The policy implications of these findings are discussed in the conclusion.
\end{abstract}

\section{Keywords}

suburbanisation, reverse commuting, travel behaviour, central city residents, Paris metropolitan area 


\section{Introduction}

Changes in housing and job location within metropolitan areas have been accompanied, in conjunction with other factors, such as growth in motorised travel and extension of motorway network, by profound changes in travel patterns (Anas et al., 1998; Giuliano and Dargay, 2006; Levinson and Ajay, 1994; Marshall and Banister, 2000). Common trends have been highlighted, both in North American and European metropolitan areas (Banister et al., 1997; Orfeuil, 2000): the proportions of suburb-to-suburb journeys and central city-to-suburb journeys have risen whilst the proportion of suburb-to-central city journeys has declined. These changes have been accompanied by an increase in car use, average daily distance travelled and travel speed.

Commuting journeys, i.e. home to work journeys, have largely followed these general trends (Aguiléra, 2005; Alpkokin et al., 2008; Giuliano and Small, 1993; Shearmur, 2006). The suburbanisation of jobs and housing has thus led to the development of suburb-to-suburb commuting and reverse commuting, defined as home-to-work journeys from the central city to the outskirts (Christopher et al., 1995). In US metropolitan areas, the number of central city to suburb daily commutes tripled between 1960 and 1990 (Glaeser et al., 2001). This change has contributed to an increase in the average home-to-work distance, especially for the low income central city residents who can not move to the major employment sub-centres because residential prices are too high (Cervero and Tsai, 2003; Christopher et al., 1995; Martin, 2001; Sanchez, 2008). Reverse commuting is also associated, to a certain extent, with the fact that a some high earners choose to live in the central city in order to benefit from highly valuable central amenities, even if their job is located in the suburbs: E.L. Glaeser et al. (2001) calls this the consumer city phenomenon and E. Korsu and M.H. Massot (2005) identify them as long distance commuters for sociological (but not economical or racial) reasons. 
In France, studies into the relationship between residential location and travel patterns have principally focused on people living in the suburbs. This is mainly because they have longer average commutes than central city residents. In addition, they use a car more frequently insofar as they have relatively poor access to public transport. Furthermore, central city residents have been considered both as being close to their workplace (they have the smallest average home-to-work distance (Massot and Roy, 2004)) and as having excellent accessibility to the whole of the metropolitan job market. On the one hand, central cities have kept a high proportion of jobs, and, on the other hand, they are well connected to the suburbs by both a dense road network and an efficient public transport system (Wenglenski and Orfeuil, 2004). Nonetheless, there has been a significant suburbanisation of employment, shopping and leisure activities in France over the last twenty years (Gaschet, 2002) and has led to an increase in the number of journeys, especially commutes, from the central city to the suburbs (Aguiléra and Mignot, 2004; Berroir et al., 2002). This change may have altered the overall travel patterns of central city residents, both for work and non work purpose, insofar as the two are not independent (Aguiléra, Massot and Proulhac, 2009; Bhat, 1997).

Based on data from the National Census and from travel surveys, this paper investigates the phenomenon of reverse commuting in the Paris metropolitan area over a 20 -year period and its consequences in terms of the travel behaviour of central city working residents. More precisely, we explore the two following issues.

The first issue relates to the professional profile of the reverse commuters. Compared to the US, more high-income households and highly qualified jobs are still concentrated in the central cities in France (Donzelot, 2004; Korsu, 2002). Hence, reverse commuting should involve high-income workers and thus be part of the consumer city phenomenon referred to earlier. 
The second question concerns the influence of reverse commuting on the overall travel behaviour of central city residents. In France they generally travel shorter average distances and make greater use of public transport than the suburban residents (Orfeuil, 2000). The first expected consequence should be an increase in home to work distance. However, this increase will be moderate because in France the major employment subcentres have developed relatively near to the central city (Aguiléra and Mignot, 2004; Bourdeau-Lepage and Huriot, 2005) and not in edge cities (Garreau, 1991). However, one effect of an (even small) increase in home to work distance could be a greater use of cars by central city residents, which would have a negative environmental impact. The second consequence could concern non work travel, insofar as work journeys, especially the distance travelled each day for work purposes, influence non work journeys.

The structure of the paper is as follows. The two sets of data are presented in the second part. The third part describes the changes to employment location (suburbanisation) and to central city residents (gentrification) within the metropolitan area over 20 years. In the fourth part, we analyze the growth of reverse commuting. The fifth part discusses the consequences in terms of the travel behaviour of the central city working residents. Finally, the conclusion summarizes the main findings and discusses their implications in terms of transport and land-use policy.

\section{Data and study area}

\section{$\underline{2.1 \text { Data }}$}

Two datasets have been used in this research. 1982 and 1999 census data have been used to analyse changes in population and employment location within the metropolitan area, to identify the reverse commuters and to evaluate their home to work distance. Home-to-work distance has been calculated as the Euclidean distance between the 
centroid of the arrondissement in which they live (the municipality of Paris is divided administratively into 19 arrondissements) and the centroid of the municipality where they work.

Census data does not provide us with an adequate understanding of Parisians' travel patterns, even for work related travel. It only provides the distance from home to workplace and the transport mode, but no other information, such as the number of daily journeys or the total distance travelled.

Consequently, Paris metropolitan area travel surveys (1983 and 2001) were used. Both were conducted using the same methodology: on each of the two dates, a representative sample of the Paris metropolitan area's residents were surveyed by one to one interviews using the same interview guide. Every journey, for work and non work purposes, made during 24 hours preceding the interview (a weekday) were recorded for each surveyed individual. A journey was defined as a one-purpose journey from one origin to one destination. Each journey was described using standard indicators including length, duration and mode. Only intra-metropolitan journeys were taken into account because the travel surveys only described intra-metropolitan mobility in detail (frequency, length, etc.). The sampling method was identical on both dates. In addition, the dates of the travel survey were almost identical to the ones of the census: this allowed links to be made between changes in people and job location with those in travel behaviour.

Both sets of data classified people by their socio-professional status, which is defined in France by the National Institute for Statistics and Economic Studies (INSEE). The four main categories used in this classification are: 1. "executive and intellectual professions" (referred to as 'executives' hereinafter), 2. "intermediate professions", 3. "clerical workers", and 4. "labourers". We can assume that category 1 is composed of 
individuals with the highest income, whilst individuals belonging to the category 4 have, on average, the lowest income.

\section{$\underline{2.2 \text { Study area }}$}

Paris is by far the biggest municipality in France, with about 2 million inhabitants and 1.6 million jobs (1999 census). The inhabitants of the municipality of Paris are called the Parisians.

The municipality of Paris is the central city of the biggest French metropolitan area, the Paris metropolitan area, with 11 million inhabitants (about $16 \%$ of French population) in 1999 and 5 million jobs ( $20 \%$ of national employment). It extends to about $100 \mathrm{~km}$ at its largest diameter.

The metropolitan area is usually divided into three parts: the central city (the municipality of Paris), the first crown, where job and people density is high, and the second crown where locations are more dispersed (Figure 1). The boundaries of the metropolitan area, which are of administrative nature, have not changed during the period studied.

(Figure 1)

\section{Employment suburbanisation and central city gentrification}

\section{$\underline{\text { 3-1 Employment suburbanisation }}$}

The municipality of Paris has lost almost 209,000 jobs (-11.5\%) between 1982 and 1999 whilst the two crowns have gained 543,000 jobs $(+18 \%)$. The municipality of Paris contained $38 \%$ of the metropolitan jobs in 1982 but has only $32 \%$ today.

As in most metropolitan areas, several employment sub-centres have developed or gained in strength (Aguiléra, 2005). The biggest (in terms of total number of jobs) are located in the first crown and are close to the central city, in its surrounding 
municipalities, such as the La Défense business centre in the western part of the first crown.

As in most French metropolitan areas, the suburbanisation of employment in the Paris metropolitan area has been very variable in different economic sectors. Hence, the nature of the jobs located in the municipality of Paris has changed considerably over the period studied (Table 1). In practice, the net decrease in central city jobs is the result of a significant increase in the number of jobs in the executive and intermediate professions, accompanied by a comparatively greater decrease in clerical and labourer jobs. This indicates that the central city has remained attractive for the service industries, and especially for business services (Halbert, 2004). This attractiveness of the central city for the service sector has been observed in other metropolitan areas in France (Aguiléra, 2003) and internationally (Baro and Soy, 1993; Coffey, Drolet and Polese, 1996).

\section{(Table 1)}

Employment in the labourer category has diminished since 1982 not only in the central city but also in the crowns and especially in the first crown (Table 1). Clerical jobs have increased outside the municipality of Paris (in both crowns) because of the strong growth in services in these areas, which is mainly due to population growth. The number of jobs in the executive and intermediate professions has increased much more in the crowns, especially the first one, than in the municipality of Paris. A large part of this change is due to the development of the La Défense business centre.

\section{3-2 Central city gentrification}

The number of working Parisians only decreased slightly (-3\%) during this 20 -year period. The change in professional status of the central city residents has been significant: low-income residents have largely been replaced by high-income residents. 
The number of clerical workers living in Paris decreased by $28 \%$, and the number of labourers by $50 \%$, whilst the number of executives living in the French capital grew by $57 \%$ and the number of intermediate professions by $14 \%$. This gentrification process has been observed in most French central cities over these two decades (Donzelot, 2004; Korsu, 2002). It results in both an overall decrease in the number of labourers, as the economy becomes more and more service sector based, and a specific decrease in the number of low-wage earners living in the central cities because of the huge increase in housing prices.

\section{4- Growth of reverse commuting}

As expected, reverse commuting has increased in the Paris metropolitan area together with the suburbanisation of employment. The number of central city residents working in the municipality of Paris (called the non reverse commuters) fell by $10 \%$ whilst the number of reverse commuters increased by almost $25 \%$ over the twenty year period: $+17 \%$ in the first crown and $+43 \%$ in the second one (Table 2). As a result, the proportion of Parisians working in the municipality of Paris fell during this period by six percent, from $77 \%$ to $71 \%$, but this is still high and the same is true for all central cities in France (Massot and Roy, 2004).

(Table 2)

The overall number of reverse commuters has grown because the increase in the number of reverse commuters for the high-income categories is greater than the decrease in the number of labourers (Table 2). Specifically, the number of executive reverse commuters has doubled whilst the Parisian executive population has grown by only $56 \%$ during this period. However, the number of Parisians working in the central city (the non reverse commuters) has also grown for executives and intermediate professions where both the number of residents and the number of jobs located in the central city have risen. On the 
contrary, the number of non reverse commuters has fallen for the low-income categories because of the reduction in central city jobs and residents.

One of the consequences of this is a notable change in the reverse commuters' profile over 20 years. $50 \%$ of the reverse commuters were executives in 1999 whilst $33 \%$ of them were 20 years earlier and only 9\% were labourers compared with $20 \%$ in 1982. This evolution is a direct effect of the gentrification of the central city.

The gentrification is due to the specific amenities (cultural, etc.) that are found in the central city. In particular, the fact that high-income jobs continue to be located in the municipality of Paris shows that it remains very attractive: this is confirmed by the fact that the number and the proportion of Parisians who have a job in the central city has grown for executives over the 20 year period. In addition, the proportion of the central city positions held by Parisians has also increased for executives (from $47 \%$ to $53 \%$ ) and remained stable for the intermediate category (40\%), whilst falling for low-income jobs (from $36 \%$ to $33 \%$ ). The latter are increasingly held by suburban residents who can not afford to live in the central city because the prices are far higher than in the rest of the metropolitan area.

The proximity of sub-centres providing high qualified jobs obviously contributes to the attraction of the central city for executives and intermediate professionals and, thereby, the gentrification process. Three quarters of reverse commuters work in the first crown and the proportion working in its western section has grown over last the 20 years.

\section{5- Impact on weekday travel patterns of central city working residents}

This fifth part of the paper aims to evaluate the consequences of the development of reverse commuting on the weekday travel behaviour of working residents of the central city. The analysis concerns both work journeys and non work journeys. 
The daily travel behaviour of the working Parisians is described using standard indicators including the number of journeys, the distance, the time devoted to transport and the different means used.

\section{5-1 Impact on the number of journeys}

Since 1983, the average number of daily journeys made by the working residents of the central city has diminished from 4.0 to 3.8 (-8\%) (Table 3). A similar reduction has been observed for all the working residents of the metropolitan area and is related to the reduction in the average number of work journeys (whereas the number of non work journeys has increased slightly). This reduction is related, firstly, to the increase in the average home to work distance and the reduction in the number of journeys between the workplace and the place of residence, especially at lunch time, and, secondly, to the decrease in the number of business journeys (those which are internal within the metropolitan area).

\section{(Table 3)}

The development of reverse commuting has accelerated the decrease in the number of daily journeys especially the number of daily work journeys made by working central city residents. In practice, the reduction in work related journeys has been twice as great for Parisians with a job located outside the municipality of Paris $(-12 \%)$ than for those with a workplace that is located inside the central city $(-6 \%)$ (Table 4). This difference is difficult to explain but it may be related to the fact that the average home to work distance of the reverse commuters has increased $(+3 \%)$ over the period studied while it has not for the non reverse commuters. In addition, both reverse and non reverse commuters have reduced the average number of their business journeys.

(Table 4)

\section{5-2 Impact on distance and time travelled}


The average distance travelled daily by a working Parisian has only slightly increased during the period studied, from $14.5 \mathrm{~km}$ to $15.5 \mathrm{~km}(+7 \%)$ (Table 3). Firstly, the impact of the increase in the average home to work distance, which is due to the increase in the number of reverse commuters, has been mitigated by the decrease in the number of work journeys. Secondly, the increase in the average distance travelled daily by working Parisians is due to the increase in the average length of non work journeys combined with the growth in reverse commuters: this group have longer home to work distances and most non work journeys are made between the workplace and the place of residence (Bhat, 1997).

In addition, time devoted to transport has remained nearly stable (about 95 min per day) for the working Parisians (Table 3). Time devoted to non work journeys has increased because the number of non work journeys has increased but this has been compensated for by the decrease in time devoted to work journeys, which has been more pronounced for the reverse commuters who have had a greater reduction in the number of their work journeys.

\section{$\underline{\text { 5-3 Impact on use of different means of travel }}$}

It is notable that in a metropolitan area where car use increased during the period considered, car use decreased for the working Parisians, from 26\% to 23\% (all travel purpose being considered) on a given weekday (Table 5). The number of kilometres travelled daily by car by the central city working residents has only slightly increased. The overall environmental impact is slightly negative but more moderate than one might expect because the number of reverse commuters has grown greatly and each of them travel more kilometres by car each day than if their jobs were located in Paris. Parisians working in the first crown have reduced their car use and increased their use of public transport because of the concentration of employment in the west (La 
Défense). Car use has remained stable for Parisians working in the second crown and public transport has only fallen slightly. Despite a strong employment growth in the second crown during the period studied, the number and location of employment subcentres have not changed greatly (Aguiléra, 2005).

(Table 5)

However, one must also take into account the fact that the proportion of journeys (and the number of kilometres) made by two-wheeled vehicle users has increased significantly (from $1 \%$ to $4 \%$ ) over this period for the Parisians (Table 5), which is negative from an environmental point of view. Car use has been replaced by the use of two-wheeled vehicles for some non reverse commuters. This is due to increased traffic congestion within the central city that makes the journeys faster by two-wheeled vehicle.

\section{$\underline{5-4 \text { Analysis by socio-professional group }}$}

The main difference in travel behaviour by socio-professional group concerns travel means. The increase in the use of public transport has been much greater for executives: $59 \%$ of their daily journeys were made by car in 1983 and only $45 \%$ in 2001, whilst the proportion of journeys made by public transport has increased from $21 \%$ to $33 \%$ during the same period. The main reason for this is the concentration of executive jobs in La Défense which is linked to the central city by the subway and rapid transit systems. At the same time, car use has almost doubled for those labourers whose jobs are located outside the municipality of Paris because their workplaces are more dispersed and less well connected to the public transit network.

\section{Conclusion: main findings and policy implications}

During the last twenty years, the municipality of Paris has lost many jobs but few working inhabitants. At the same time, employment was developing in the suburbs and 
reverse commuting has increased. However, Parisian reverse commuters and their workplace locations are very different from those found in most the US cities. On the one hand, the central city has kept a strong attraction for high-income individuals and this attraction has grown significantly over 20 years (gentrification). On the other hand, the suburbanisation of executive jobs has mainly concerned areas located very close to the central city, mainly because the public authorities have encouraged the development of the business district of La Défense in the west of the municipality of Paris. Consequently, reverse commuters in the Paris metropolitan area are mainly high income professionals whose workplace is located very near to the central city.

The average home-to-work distance has therefore only slightly increased in 20 years and changes in travel patterns have been relatively moderate. The average distance travelled per day by the central city residents has only increased slightly, time spent travelling has remained quite stable, and, more surprisingly, car use has decreased, whilst the proportion of journeys made by two-wheeled users has increased. However, the situation is obviously more difficult for low income individuals (especially labourers) whose job is located outside Paris and whose level of car use has increased significantly during the last 20 years because their workplaces have become dispersed and are located in areas that are less well served by public transport.

These findings have several implications in terms of transport and land-use policy. Firstly, we have confirmed that the choice of transport means is very dependent on the workplace and, more precisely, on the way that residences and workplaces are connected. If public transport is of sufficient quality, as is the case between Paris and La Défense, then its use rate is high, even by high income residents who have greater access to a car. To reduce car use, public transport must be improved not only between 
Paris and the major employment sub-centres in the metropolitan area but also between the sub-centres themselves, which is not at all the case at present.

Secondly, this paper has shown that the gentrification of the municipality of Paris was (partly) linked to its capacity to attract high qualified jobs and to its proximity to subcentres that concentrate such employment. However, these jobs could be attracted by more remote locations in the future and public authorities should think about the possible consequences of this for the attractiveness of the municipality of Paris.

Our findings also highlight the fact that a growing share of the low income central city jobs are held by suburban residents (which is the opposite case for high income categories). This trend is directly responsible for increased car use within the metropolitan area (Aguiléra, 2005). Obviously, there is a severe lack of affordable housing in the central city (Korsu and Massot, 2005). Residential property prices have increased threefold over the last ten years in the municipality of Paris, which is by far the most expensive municipality in the metropolitan area. Public authorities should be aware of this spatial mismatch which has negative environmental and social consequences.

\section{References}

Aguiléra, A. (2003) Service Relationship, Market Area and the Intra-metropolitan Location of Business Services. The Service Industries Journal, 23, 1, 43-58.

Aguiléra, A. (2005) Growth in Commuting Distances in French Polycentric Metropolitan Areas : Paris, Lyon and Marseille. Urban Studies, 42, 9, 1537-1547.

Aguiléra A., Massot, M.H. and Proulhac L. (2009) Exploring the relationship between work and travel behaviour on weekdays. An analysis of the Paris Region travel survey over 20 years. Transportation Research Record, to be published. 
Aguiléra, A.and Mignot, D. (2004) Urban Sprawl, Polycentrism and Commuting. A Comparison of Seven French Urban Areas. Urban Public Economic Review, 1, 1, 93114.

Alpkokin, P. Cheung, C. Black, J. and Hayashi, Y. (2008) Dynamics of clustered employment growth and its impact on commuting patterns in rapidly developing cities. Transportation Research Part A, 42, 3, 427-444.

Anas, A. Arnott, R. and Small K.A. (1998) Urban Spatial Structure. Journal of Economic Literature, 36, 1426-1464.

Banister, D., Watson, S. and Wood C. (1997) Sustainable cities, transport, energy and urban form. Environment and Planning B, 24, 125-143.

Baro, E. and Soy, A. (1993) Business Service Location Strategies in the Barcelona Metropolitan Region. The Services Industries Journal, 13, 2, 103-118.

Berroir, S., Mathian, H. and Saint-Julien, T. (2002) Déplacements domicile-travail: vers le polycentrisme?, Insee Ile de France Regards, 54, 5-8.

Bhat, C.R. (1997) Work travel mode choice and number of non-work commute stops. Transportation Research Part B, 31, 1997, 41-54.

Bourdeau-Lepage, L. and Huriot, J.M. (2005) On poles and centers: cities in the French style. Revista de Economia Publica Urbana, 3, 13-36.

Cervero, R. and Tsai, Y.H. (2003) Job access and reverse commuting initiatives in California: Review and assessment. Transportation Research Record, 1859, 78-86.

Christopher, E.J. Rogus, M. and Soot, S. (1995) Changes in the direction of urban travel for the Chicago Area, 1970 to 1990. Transportation Research Record, 1477, 48-57.

Coffey, W. J., Drolet, R. and Polese, M. (1996) The intra-metropolitan location of high order services : patterns, factors and mobility in Montreal. Papers in Regional Science, The Journal of the Regional Science Association International, 75, 3, 293-323. 
Donzelot, J. (2004) La ville à trois vitesses : gentrification, relégation, périurbanisation. Esprit, mars-avril.

Garreau, J. (1991) Edge cities. Doubleday, New York.

Gaschet, F. (2002) The new intra-urban dynamics: suburbanisation and functional specialization in French cities. Papers in Regional Science, 81, 1, 63-81.

Giuliano, G. and Dargay, J. (2006) Car ownership, travel and land use: a comparison of the US and Great Britain. Transportation Research Part A, 40, 106-124.

Giuliano, G. and Small, K.A. (1993) Is the Journey to Work Explained by Urban Structure?. Urban Studies, 30, 9, 1485-1500.

Glaeser, E.L. Kolko, J. and Saiz, A. (2001) Consumer City. Journal of Economic Geography, 1, 27-50.

Halbert, L. (2004) The Decentralization of Intra-metropolitan Business Services in the Paris Region: Patterns, Interpretation, Consequences. Economic Geography, 80, 4, 381404.

Korsu, E. (2002) Mécanismes et implications des disparités socio-spatiales et de la segregation urbaine: le cas de la région parisienne. Thèse en urbanisme, aménagement et politiques urbaines, Université Paris XII.

Korsu, E. and Massot, M.H. (2005) Achieving a Jobs-Housing balance in the Paris Region. The potential of reducing car traffic. Conference of the ERSA, Amsterdam. Levinson, D.M. and Ajay, K. (1994) The rational locator: why travel times have remained stable. Journal of the American Planning Association, 60, 3, 319-332.

Massot, M.H. and Roy, E. (2004) Lieux de vie, lieux de travail: 15 ans d'évolution. Rapport INRETS.

Marshall, S. and Banister, D. (2000) Travel reduction strategies: intentions and outcomes. Transportation Research Part A, 34, 5, 321-338. 
Martin, R.W. (2001) Spatial Mismatch and Costly Suburban Commutes : Can Commuting Subsidies Help? Urban Studies, 38, 8, 1305-1318.

Orfeuil, J.P. (2000) L'évolution de la mobilité quotidienne. Synthèse INRETS, 37.

Sanchez, T.W. (2008) Poverty, policy, and public transportation. Transportation Research Part A, 42, 5, 833-841.

Shearmur, R. (2006) Travel from Home: An Economic Geography of Commuting Distances in Montreal, Urban Geography, 27, 4, 330-359.

Wenglenski, S. and Orfeuil, J.P. (2004) Differences in Accessibility to the Job Market According to Social Status and Place of Residence in the Paris Area. Built Environment, $30,2,116-126$. 
Figure 1: The Paris metropolitan area

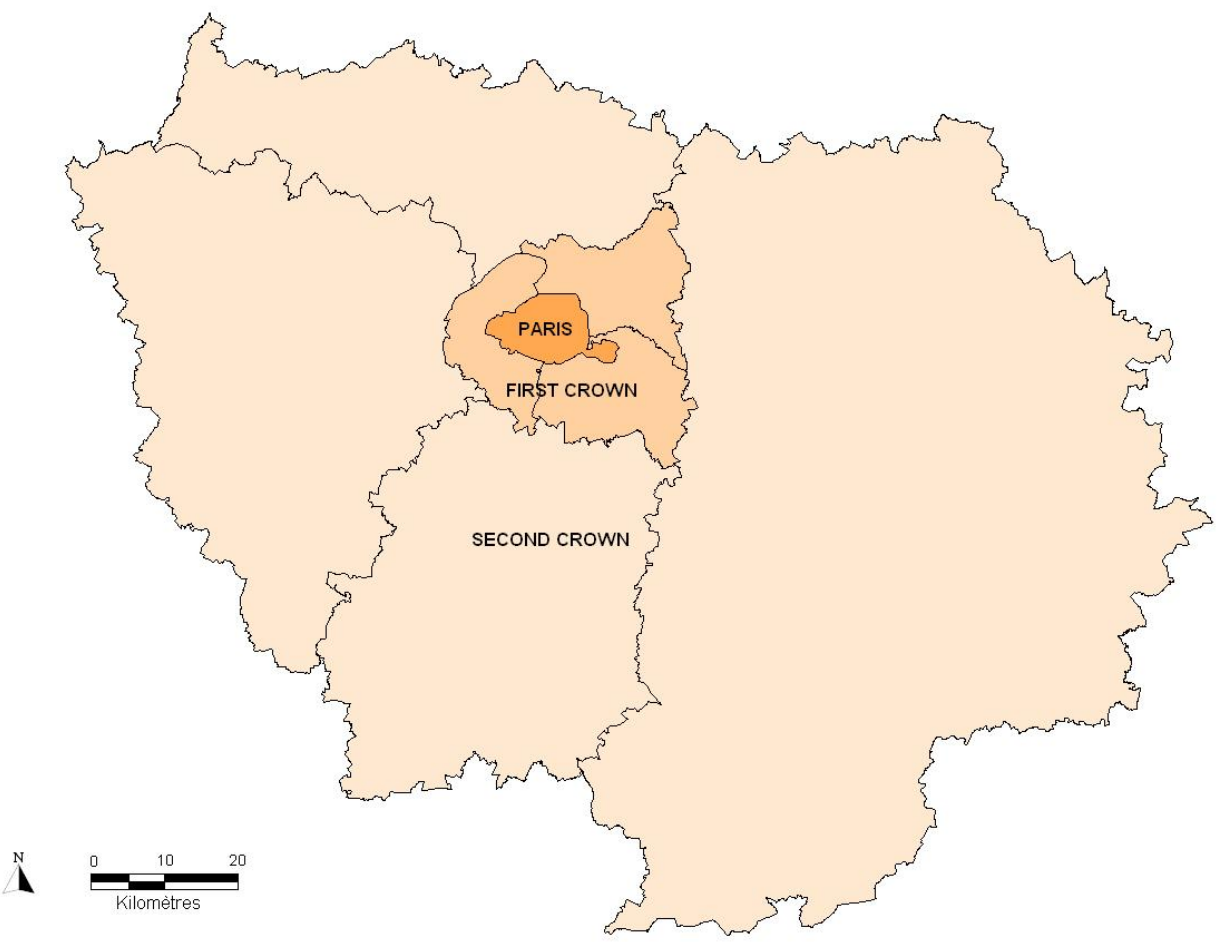


Table 1: Employment in the Paris metropolitan area between 1982 and 1999 by socioprofessional status

\begin{tabular}{c|c|c|c|c} 
& Executive & Intermediate & Clerical & Labourers \\
& & professions & workers & \\
\hline Paris & $+21 \%$ & $+7 \%$ & $-26 \%$ & $-40 \%$ \\
\hline First crown & $+78 \%$ & $+29 \%$ & $+8 \%$ & $-36 \%$ \\
\hline Second crown & $+103 \%$ & $+64 \%$ & $+34 \%$ & $-24 \%$ \\
\hline Total & $+55 \%$ & $+30 \%$ & $-1 \%$ & $-27 \%$
\end{tabular}

Source: authors' calculations from census data 
Table 2: Change in Paris residents' workplace by socio- professional status between

1982 and 1999

\begin{tabular}{c|c|c|c|c|c} 
& Executives & Intermediate & Clerical & Paris \\
& & professions & workers & Labourers & working \\
& & & & & inhabitants \\
\hline Paris & $+38 \%$ & $+10 \%$ & $-31 \%$ & $-45 \%$ & $-10 \%$ \\
\hline First crown & $+103 \%$ & $+25 \%$ & $-10 \%$ & $-57 \%$ & $+17 \%$ \\
\hline Outside Paris region & $+73 \%$ & $-6 \%$ & $+73 \%$ & $-14 \%$ & $+38 \%$ \\
\hline Total & $+57 \%$ & $+14 \%$ & $-28 \%$ & $-48 \%$ & $-3 \%$
\end{tabular}

Source: authors' calculations from census data 
Table 3: Travel patterns of working Parisians by journey purpose in 2001 and 1983

\begin{tabular}{c|c|c|c} 
& Frequency & $\begin{array}{c}\text { Distance } \\
(\mathbf{k m})\end{array}$ & $\begin{array}{c}\text { Duration } \\
(\mathbf{m i n})\end{array}$ \\
\hline $\mathbf{2 0 0 1}$ & & & \\
\hline Return home & 1.3 & 5.8 & 36.5 \\
\hline Non work & 1.2 & 2.9 & 21.6 \\
\hline Work & 1.3 & 6.8 & 37.1 \\
\hline All purpose & 3.8 & 15.5 & 95.2 \\
\hline $\mathbf{1 9 8 3}$ & & & \\
\hline Return home & 1.4 & 5.2 & 35.3 \\
\hline Non work & 1.1 & 2.4 & 19.8 \\
\hline Work & 1.5 & 6.9 & 41.5 \\
\hline All purpose & 4.0 & 14.5 & 96.6
\end{tabular}

Source: authors' calculation from Travel Surveys data 
Table 4: Travel patterns of working Parisians by workplace location in 2001 and 1983

\begin{tabular}{c|c|c|c} 
& Frequency & Distance & Duration \\
\hline $\mathbf{2 0 0 1}$ & & $(\mathbf{k m})$ & $(\mathbf{m i n})$ \\
\hline Non reverse commuters & 3.9 & 10.6 & 85.6 \\
\hline Reverse commuters & 3.5 & 23.8 & 111.4 \\
\hline All working Parisians & 3.8 & 15.5 & 95.2 \\
\hline $\mathbf{1 9 8 3}$ & & & \\
\hline Non reverse commuters & 4.1 & 10.4 & 88.0 \\
\hline Reverse commuters & 3.9 & 24.8 & 118.8 \\
\hline All working Parisians & 4.0 & 14.5 & 96.6 \\
\hline Source authors' & & &
\end{tabular}

Source: authors' calculation from Travel Surveys data 
Table 5: Travel means used for daily journeys of working Parisians in 1983 by workplace location

\begin{tabular}{|c|c|c|c|c|c|c|}
\hline & $\begin{array}{c}\text { Public } \\
\text { transport }\end{array}$ & Car & $\begin{array}{c}\text { Two- } \\
\text { wheeled }\end{array}$ & On foot & \begin{tabular}{|c|} 
Other \\
mechanised \\
methods
\end{tabular} & All means \\
\hline \multicolumn{7}{|l|}{2001} \\
\hline Non reverse commuters & $37 \%$ & $17 \%$ & $5 \%$ & $40 \%$ & $1 \%$ & $100 \%$ \\
\hline Reverse commuters & $37 \%$ & $36 \%$ & $2 \%$ & $25 \%$ & $1 \%$ & $100 \%$ \\
\hline All working Parisians & $37 \%$ & $23 \%$ & $4 \%$ & $35 \%$ & $1 \%$ & $100 \%$ \\
\hline \multicolumn{7}{|l|}{1983} \\
\hline Non reverse commuters & $38 \%$ & $21 \%$ & $13 \%$ & $9 \%$ & $1 \%$ & $100 \%$ \\
\hline Reverse commuters & $34 \%$ & $41 \%$ & $12 \%$ & $4 \%$ & $1 \%$ & $100 \%$ \\
\hline All working Parisians & $37 \%$ & $26 \%$ & $1 \%$ & $35 \%$ & $1 \%$ & $100 \%$ \\
\hline
\end{tabular}

Source: authors' calculation from Travel Surveys data 